\title{
The Role of Religion in Higher Education Funding:Special Reference to Hinduism and Buddhism in Malaysia
}

\author{
Masitoh Ahmad (Corresponding author) \\ Department of Usuluddin, Faculty of Islamic Studies \\ Sultan Azlan Shah University, 33000 Kuala Kangsar, Perak. \\ Tel: +60123337008 Email: masitohahmad@kuisas.edu.my \\ Muhammad Syahid Ahmad \\ Department of Usuluddin, Faculty of Islamic Studies \\ Sultan Azlan Shah University, 33000 Kuala Kangsar, Perak. \\ Tel: +60129189192 E-mail: syahid@kuisas.edu.my \\ Jamil Hashim \\ Department of Usuluddin, Faculty of Islamic Studies \\ Sultan Azlan Shah University, 33000 Kuala Kangsar, Perak. \\ Tel: +60196990177 E-mail: jamilhashim@kuisas.edu.my \\ Wan Sabri Wan Yusuf \\ Sultan Azlan Shah University, 33000 Kuala Kangsar, Perak. \\ Tel: +60192806412 E-mail: wansabri@kuisas.edu.my
}

\begin{abstract}
Religion is one of the recognised factors which play important roles in changing human lives. It influences various aspects of man's life spectrum. Generally, each and every religion promotes man's well-being and brings guidance to improve man's lives psychologically, sociologically, spiritually and economically. From the economic point of view, every religion therefore provides sacred instruments to improve the society. In Hinduism and Buddhism, dana (charity), through redistribution of wealthis one of the economic sacred instruments practised to enhance man's well-being. Therefore, Hinduism and Buddhism, amidst the other major world's religionsin Malaysia, strive to play their own vital role in inculcating the sense of awareness among its adherents on the importance of charity and knowledge; for charity is known through knowledge (dharma). Both religions maintain that knowledge and hence, education has vital values and roles in order for man to attain happiness and prosperity in life, physically and spiritually.
\end{abstract}

This research focuses on the economic role of religion, specifically Hinduism and Buddhism, in developing the society's well-being through funding for higher education in contemporary Malaysia. It discusses the concept of dana (charity) and its significance in the teachings of the two Indian religions, as well as factors encouraging their adherents to the practice of giving and charity. This paper will also examine the role and dana management of two religious institutions, namely the Penang Hindu Endowments Board (PHEB) and Malaysian Buddhist Association in higher education financing.

This research incorporates both library research and field studies, wherein survey and interview methods are applied. It suggests that the doctrine of dana in Hinduism and Buddhism plays important roles for the well-being of the society in contemporary Malaysia, specifically in economy and education. 


\section{Keywords: Religion, dana, Hinduism, Buddhism, higher education}

\section{Introduction}

Malaysia is a well-known country with its pluralistic, multi-religious society.Among the major religions of the world professed in Malaysia are Islam, Buddhism, Hinduism, Christianity and Sikhism. Generally, religion has been a recognised factor which plays important roles in changing human lives psychologically, sociologically, spiritually and economically. Economically, in improving human lives, e.g. charity (dana) is one of the sacred instruments which improves man's well-being through redistribution of wealth.

Therefore, every major religionin Malaysia strives to playits own vital rolein inculcating the sense of awareness among its followers on the importance of charity and knowledge, for charity is known through knowledge (dharma). Each and every religion maintains thatknowledge and hence, educationhas vital values and roles in order for man to attain happiness and prosperity in life, physically and spiritually.

\section{The Concept of Dana}

The tradition of charity finds itself in every religion across the world. It is one ofthe principles which are accepted globally and universally accepted as one of the most basic human virtues. In major world religions, it is also known as dana(Hinduism, Buddhism, Jainism and Sikhism), sadaqah, zakat and waqf(Islam), charity and tithe (Christianity). Literally, the concept of dana loosely refers to the act of charitable contributions. The concept therefore expands beyond the boundary of currency to food, medicine, kindness, compassion, knowledge and all which may be given as gifts. The concept is purely discretionary, in the sense that there is no obligation to give- and that it should result out of the donor's free will (Majumdar, 2015).

\section{The Concept of Dana in Hinduism}

As one of the oldest religious traditions, Hinduism also subscribes to the concept of dana as a practice of virtue. Compassion and assistance to others in need is a highly cherished value in Hinduism and has been recognised as the most potent source of punya (merit), where itconsequently improves one's karma in the succeeding birth (Majumdar, 2015).

In Hinduism, the concept of endowment could be classified into two categories, namely dana and utsarga. Technically dana can be referred to as "the transfer of property from one person to another, so long as the number of beneficiaries is fixed." (Agarwal, 2010). However, if the property is dedicated for general public use, it is then known asutsarga. The differences between the two based on the determination of the beneficiaries.

Generally, the purpose of dana in Hinduism can be classified into three categories. The highest level of danais Jyeshth, that is, when a property is given in order to achieve moksha. It is considered to be a part of the duty (dharma) of the individual and increases their religious merit (punya) (Tomalin, 2009). The second level is Madhyam, that iswhen it is given out of pity or kindness and the third level is Kanishth, that iswhen a property is given to achieve one's own selfish ends (Agarwal, 2010).Other objectives of dana in Hinduism according to Majumdar (2014), are to attain moksha (punya), as an act of repentance (prayaschita), as an act of renouncing the world (aparigraha), and as an act of compassion (karuna). These four objectives can be further categorised into two, namely; for self-interest (punya and prayaschita) and as a selfless duty towards others (aparigraha andkaruna).

For each transaction of dana, there are further six components to be presented, namely; donor, accepter, purification, legitimate object for donating, place and time. For each of these components, there are conditions to be fulfilled 
before the transaction takes place. Agarwal (2010), has elaborated the four kinds of dana in Hinduism. The first, according to him is in the form of works of public welfare, which is known as dhruv. The second form is whatever that is given on a daily basis, known as nitya. The third is known as kamya, which is given with intention or desire and the final kind is naimittik, which is motivated by auspicious times, occasion or by the recipient's virtues (Agarwal, 2010).The transaction of danahowever, could be nullified by these three factors. The first is by regretting the act. The second factor is when dana which is given without shraddha (ritual) and finally when the receiver is scolded afterwards (Agarwal, 2010).

\section{The Concept of Dana in Buddhism}

One of the most prominent ethical activities in Buddhism is dana(giving). It forms a basis for further moral and spiritual development by allowing the Buddhists to practise selflessness, anatta (non-self), non-possessive as well as non-attachment feelings to material objects(Majumdar, 2014).The importance of dana in Buddhism can be seen in its place as the first of ten paramis (virtues leading towards perfection), namely dana-parami (virtue in alms-giving or generosity) besides others such as; sila-parami (morality), nekkhamma-parami (renunciation), pannaparami (wisdom), viriya-parami(great effort or perseverance), khanti-parami (forbearance or patience), sacca-parami (truthfulness), aditthana-parami (determination), mettaparami (all-embracinglove) and upekkhaparami (equanimity) (U Ba Khin, 1991).

The importance of dana in Buddhism has been proven throughout its development history where the spread of Buddhism at its early stage from India throughout Asia as it is today initially owes to the dana of King Bimbisara who donated a land which became the first foundation for the Buddhist monastic institution. (Urubshurow, 2008).Other well-known Buddhist historical danaexamples including figures such as the courtesan Amrapali who donated her mango grove for the early Buddhist community to reside safely during the rainy season and King Asoka's edict which focuses on the importance of dharma-dana (giving) and dharma-samvibhaga (wealth distribution), to encourage his subjects to consider the needs of religious ascetics and the poor [besides dharma sambandha (kinship) and dharma-rati (moral pleasure)](Urubshurow, 2008).

According to Agarwal (2010), there are four main forms of dana mentioned in Pali texts, namely; vihar dana, bhiksha, maha danaand dana shala. The first refers to the construction of a monastery for the monks. The second form refers to a form of charity that which is given out of piety. The third form refers to offerings to monks while the final form, danashala refers to the building dedicated to monks where food is offered on a daily basis. These four forms can be further elaborated into six categories of dana which are quite similar to the concept of Islamic waqf, namely aramaropa dana (garden or orchard), vanaropa dana (forestation), setukaraka dana (roadways or bridges), papa dana (water), udapana dana (pools) and upassaya dana (shelter)(Sikkhananda, 2010). Besides these four forms, Sikkhananda, (2010) has also highlightedother categories of danawhich has been derived from AbhidammaPitaka, namely rupa dana (material or forms), sadda dana (hearing) such as greetings or music, gandha dana (smell) such as perfume, rasa dana (taste) such as sweetness, photthabba dana (touch) such as comfort, and dhamma dana (mental) such as medical and freedom. However, apart from these, there are alsocategories of unlawful things which are forbidden to be distributed as dana, namely majja dana (intoxicants), Itthi dāna (sexual oriented), cittakamma dana (pornographic materials), sattha dana (weaponry) and visa dana (poison). 


\section{Religious InstitutionsFunding for Higher Education in Contemporary Malaysia}

\section{The Penang Hindu Endowments Board (PHEB)}

PHEB is the sole Hindu institution which plays important roles in financing education institutions in Malaysia. It has been established in 1906 as a statutory body through the Hindu Endowments Act. The board comes under the jurisdiction of the Ministry of Women, Family and Community Development and the Penang State Government. (Muthiah. M. R. (2016, May 18). Personal Interview)

Generally, its main role is to administer endowments placed under its administration. The forms of endowments involved vary from properties, trusts, funds and scholarships. Among the main endowments administered by the Board aretemples (ArulmiguBalathandayuthapani Temple, Sri MahaMariamman Temple,Sri Kunj Bihari Temple, Sri Ramar Temple, SriSelvaVinayagar Hindu ParipalanaDevasthanam), burial grounds, multipurpose hall (Dewan SreeMariamman), and properties such ashouses, lands, restaurants and shop lots.(The Penang Hindu Endowments Board, (2016, May25) retrieved from http:// www.hebpenang.gov.my)

To date, PHEBholds approximately RM670 million worth of property. From this number, it redistributes its wealth to the society through funds for medical purposes, schools events, sports training, halfway-houses and hospitals. In terms of education, it offersscholarships and funds - to all members of society regardless of religion - for bachelor's degree, diploma (Penang Skills Development Centre (PSDC) and skills classes(Tan Chong Technical Institute). The worth number of scholarships offered is ascending each year as for 2016; it coversup to RM582,000 for 297 students.(Muthiah, M. R.(2016, May 18). Personal Interview)

\section{Malaysian Buddhist Association (MBA)}

MBA was established on $19^{\text {th }}$ of April, 1959. The objectives of MBAis to enhance the propagation and research of the Dharma, to enhance and implement the Buddhist religious order, to foster Buddhist culture and Buddhist education, to maintain a registry of all the Buddhist temples and nunneries, to rectify incorrect practices, to defend the dignity and creditability of Buddhism, and to enhance unity and friendship of Malaysian Buddhists. (Malaysian Buddhist Association. (2016, May 26)Retrieved from http://www.malaysianbuddhistassociation.org/ index.php/contact-us.html

MBA plays a vital role in promoting social welfare and charitable undertakings. In order to fulfil its social responsibility, MBA provides education and healthcare to public regardless of race, ethnicity or religion. Currently, MBA possesses its owneducational institution, medical centre for haemodialysis and acupuncture and old folks home whereby the source of finance of those institutions is acquired fully from public donation. MBA is also responsible for monitoring the smooth-running of Buddhist temples administration. At present, there are 1500Buddhist temples throughout Malaysia registered under MBA and placed under its patronage.(Loo Keat Seng,(2016, May 26). Personal Interview).

In the field of education, MBA is a leading Buddhist association funding for higher education. This can be seen obviously in the establishment of Malaysian Buddhist Institute (MBI). MBI is a Buddhist institute of higher education providing formal training in the Chinese language to prepare candidates for the sangha orders (monks and nuns) in the Mahayana tradition. It is located in Penang, Malaysia, and was established on September 18, 1969. MBI provides various courses in Buddhist studies leading to Certificate and Diploma levels as well as short training courses to enhance leadership and management skills for Buddhist. (Xin Khai.(2016, May 18). Personal Interview). 
Besides comprehensive trainings for Chinese Mahayana monks and nuns, MBIalso runs a kindergarten and provides public classes for calligraphy, cooking, music and skills(language class). The institution also gives other Buddhistsan opportunity for more in-depth study of Buddhism through dharma teaching classes and lectures conducted by monks and nuns. All the courses are freely available to the public in line with the Institute's charitable objectives.(Loo Keat Seng,(2016, May 26). Personal Interview).

As one of the institutions under the auspices of the MBA, MBI is fully funded by MBA. The budget allocation for this higher institution amounts RM 500,000 annually. MBI offers scholarships for Buddhist studies and research, and provides facilities for educational purposes such as library, food and accommodation freely. Presently, MBIis giving a scholarship for 20 students who are doing Buddhist studies at this higher institution. (Xin Khai.(2016, May 18). Personal Interview).

\section{Conclusion}

The practice ofgiving is universally recognised as one of the most humane virtues and accepted as a noble deed that contributes to social harmony in the teachings of all world religions; be it a revealed religion like Islam and Christianity or man-made religion such as Hinduism, Buddhism, Jainism and Sikhism. It is an undeniable fact that religious beliefs play a crucial role as a driving factor to the practice of giving. In Hinduism and Buddhism, the belief in the doctrine of causality (karma), law of cause and effect-good causes and intentions leads to good results; evil causes lead to evil results-and rebirth (samsara)encouraged their followers to always practise danafor it is not onlyone of the meritorious deedsthat bring mankind happiness in the future, but also strengthen his efforts to attain nirvana, the utter cessation of suffering (dukha).

Buddhism and Hinduism hold thatignorance (avidya) or inability to see the truth about things, to see things as they really areis one of the factors that leads to samsara. Therefore, knowledgeis very crucial in the teaching of the two religionsas it demonstrates as one of the means toattain their ultimate goal, that is the emancipation from the suffering of rebirth or repeated existence of samsara.Both religions consider mokhsha and nirvanaachievable by removingand uprooting ignorance.

Therefore, it is obvious that the role of religion in education is vital. It motivates human being to acquire knowledge in order for them to achieve prosperity and wisdom in life. In Buddhism, the layman is encouraged not only to gain knowledge for the well-being of their life, but also to practise giving for educational purpose particularly for the community of sangha and those who devote themselves to the study of Buddhism. This is similar to Hinduism, in which it allocatessome portion of dana or giving for education. In Malaysia, its implementation can be seen through many aspects especially in lower and higher level of education by institution like the Penang Hindu Endowments Board (PHEB) and Malaysian Buddhist Association (MBA). The role of religion therefore can be seen actively propagating the importance of knowledge whereby scholarships and funds are distributed for the said purpose.

\section{References}

Agarwal, S. (2010). Daan and Other Giving Traditions in India. AccountAid, Delhi, India.

Bodhi, B. (2005). Dana The Practice of Giving. Buddhist Publication Society, Sri Lanka.

Brick, D. J. (2009). The Danakanda ("Book on Gifting") of the Krrtyakalpataru: A Critical Edition and Annotated Translation. (Doctoral dissertation). Retrieved from http://hdl.handle. net/2152/7546

Buswell Jr., R. E., \& Lopez Jr., D. S. (2014). The Princeton Dictionary of Buddhism. Princeton 
University Press, United Kingdom, London.

Majumdar, A. B. (2015). India's Journey with Corporate SocialResponsibility-What Next? Journal of Law \& Commerce. 33(2) :165-205

, Zakat, Dana and Corporate Social Responsibility (April 6, 2014). Available at SSRN: http://ssrn.com/abstract=2421001

Malaysian Buddhist Association. (2016) Retrieved May 26, 2016 from http://www. malaysianbuddhistassociation.org/index.php/ contact-us.html

Pancaratra.(Doctoral dissertation). Retrieved from http://escholarship.org/uc/item/ 83r393vc

Raddock., Elisabeth, E. (2011). Listen How the Wise One BeginsConstruction of a House for Visnu: Chapters 1-14 of the Hayasirsa

Sikkhananda,B.(2010).Dana: Penjelasan Disertai dengan Cerita. ChanmyayYeiktha Meditation Center, Myanmar.

Schmucker, M. (2014). The Relevance of "Givenness" for the Indian Religious Traditions. Argument, Vol.4(1):43-54

Sucitto, A. (2016). The Graduated Path. Amaravati Publications, United Kingdom, London.

Techapalokul, S. (2015). Towards Buddhist Social Work and Happiness. Paper presented at the AEC International Buddhist Conference, Penang, Malaysia

The Penang Hindu Endowments Board. (2016) Retrieved May 25, 2016 from http:// www.hebpenang.gov.my/content/display/ article/site:hindu_endowment_boardparam:introduction-link:7705

Tomalin, E. (2007) Buddhism and Development: A Background Paper (Working
Paper No.18). Retrieved from University of Birmingham Website: http://www.birmingham. ac.uk/Documents/college-social-sciences/ government-society/rad/working-papers/wp18.pdf

Tomalin, E. (2009) Hinduism and International Development: Religions and Development Background Paper (Working Paper No.19). Retrieved from University of Birmingham Website: http://www.birmingham.ac.uk/ Documents/college-social-sciences/ government-society/rad/working-papers/wp19.pdf

Urubshurow, V. K. (2008). Introducing World Religions. Routledge, USA.

U Ba Khin, S.(1991). Dhamma Texts. U.K.: The Sayagyi U. Ba. Khin Memorial Trust.

U Silananda, S. 2012. Handbook of Abhidhamma Studies. Majujaya Indah Sdn Bhd, Kuala Lumpur, Malaysia. 